\title{
The Mediating Role of Organizational Identification in the Effect of Perceived Organizational Support on Employee Performance
}

\author{
Ergün KARA (https://orcid.org/0000-0002-7815-1111), Department of Business Administration, Osmaniye \\ Korkut Ata University, Turkey; e-mail: ergunkara@osmaniye.edu.tr
}

Gülșen KIRPIK (https://orcid.org/0000-0003-4785-9624), Department of Pharmacy Management, Adlyaman University, Turkey; e-mail: gkirpik@adiyaman.edu.tr

Attila KAYA (https://orcid.org/0000-0002-2479-5173), Department of Business Administration, Osmaniye

Korkut Ata University, Turkey; e-mail: akaya501616@gmail.com

\section{Algılanan Örgütsel Desteğin Çalışan Performansı Üzerindeki Etkisinde Örgütsel Özdeşleşmenin Aracı Rolü}

\begin{abstract}
In this study, the mediating role of organizational identification in the effect of perceived organizational support on employee performance was examined. In this context, data were collected from 414 participants working in banks in Adana and Osmaniye provinces of Turkey through a questionnaire. Confirmatory factor analysis (CFA) was applied to the scale used in the study. In addition, the goodness of fit tests and regression analysis were carried out by a structural equation model (SEM). The mediation role was tested with the Boostrap method. As a result of the study, it was determined that organizational identification has a partial mediating effect on the relationship between perceived organizational support and employee performance.
\end{abstract}

Keywords

Organizational Support, Employee Performance, Organizational Identification.

JEL Classification Codes : $\quad$ M10, M12, M19.

Öz

$\mathrm{Bu}$ çalışmada, algılanan örgütsel desteğin çalı̧̧an performansı üzerindeki etkisinde örgütsel özdeşleşmenin aracılık rolü incelenmiştir. Bu amaç doğrultusunda Adana ve Osmaniye ilindeki bankalarda çalışan toplam 414 katılımcıdan anket aracılığıyla veri toplanmıştır. Ölçek geçerliliği için doğrulayıcı faktör analizi (DFA) yapılarak, değişkenler arası ilişkiler tespit edilmiş ve yapısal eşitlik modeli (YEM) ile modelin uyum iyiliği testleri ve regresyon analizi yapılmıştır. Aracılık rolünü test edebilmek için ise dolaylı etkilerin anlamlılığına bakılmış ve bunun için boostrap yöntemi kullanılmıştır. Çalışma sonucunda örgütsel özdeşleşmenin algılanan örgütsel destek ile çalışan performansı arasındaki ilişkide kısmi aracılık etkisini gösterdiği belirlenmiştir.

Anahtar Sözcükler Örgütsel Destek, Çalışan Performansı, Örgütsel Özdeşleşme. 
Kara, E. \& G. Kırpık \& A. Kaya (2021), "The Mediating Role of Organizational Identification in the Effect of Perceived Organizational Support on Employee Performance", Sosyoekonomi, 29(49), 47-64

\section{Introduction}

Today, the increasing competition between organizations and dizzying technological developments in the globalizing world have made employees the most valuable assets of organizations. At this point, meeting the expectations of the employees and supporting them constitute one of the preliminary issues that should be taken into consideration by the management and managers in increasing organizational productivity. In line with the vision, mission and policies determined by organizations for the future, the subject they focus on most is the concept of performance. Because, performance is an important prerequisite for the survival of the organization. Considering the share of employees in organizations, it is important to identify and highlight the factors that affect their individual work performance. For this reason, one of the most fundamental issues that will enable employees to identify with the organization and increase their performance is that the top management that manages the organization provides organizational support to the employees and exhibits positive attitudes and behaviours towards them. Perceived organizational support has positive and very important effects on the individuals working in the organization. In this context, perceived organizational support is one of the premises necessary to increase employee performance.

Perceived organizational support (POS) is the positive belief of the employees towards the organization, despite the fact that the efforts and efforts made by the employees are seen and taken into account by the managers of the organization. The positive impressions of the employees who put forward their opinions, thoughts and criticisms for the organization are noticed by the top managers in the organization and in this context, financial and moral support and providing career opportunities positively affect the employees (Eisenberger et al., 1986; Yılmaz \& Görmiş, 2012; Karaalioğlu, 2019: 1). POS is that employees know that they are owned by the organization and that they are volunteers to contribute to both personal and career development. In return for such support given to the employee, the employee, who feels he is cared for by the institution, will not be indifferent to this support and will directly increase his individual performance (Erkoç, 2015: 1). Eisenberger et al. (1986) stated that the basic criterion that shows the quality of the relationship between the employee and the organization is the perception of organizational support. In addition, they explained POS as the attitudes that increase the productivity of the employees and the behaviours that make the individuals happy. Cullen-Lester et al. (2014), on the other hand, explains that POS is "the employee should be interested in his/her institution and fulfil his/her responsibilities at the highest level in return for the financial and moral support he/she receives from his/her organization".

Another important factor in increasing the performance of employees is organizational identification. Today, some complex and social change phenomena indicate that organizational identification must be absolutely necessary for organizations to analyse themselves (Lee, 1971: 214). When we evaluate the organizational identification in general, we should state that this concept is related to many concepts and it is seen as important for institutions and organizations together with cultural, global, technological and sociological 
factors. The degree of identification with the organization plays an important role in explaining the attitudes and behaviours of the employees towards the job they work in. Organizational identification is expressed as "bringing together certain characteristics of employees within the scope of their work in line with the organization's management philosophies" (Tüzün \& Çağlar, 2008). Studies have also stated that perceived organizational support (POS) positively affects the performance of employees.

The starting point of this study is whether perceived organizational support (POS) and organizational identification have a positive effect on employee performance, and whether POS has an increasing effect on employee performance. Although the effect of POS on employee performance is investigated in the literature, the fact that the role of organizational identification in this effect is not investigated reveals the importance of this study.

The research questions created within the scope of the study are as follows:

- Does perceived organizational support affect employee performance?

- Does perceived organizational support affect organizational identification?

- Does organizational identification affect employee performance?

- Does organizational identification have a mediating role in the effect of perceived organizational support on employee performance?

Within the framework of the above-mentioned research questions, in the next part of the research, firstly the relationships between concepts are explained, then the study hypotheses are tested with the field research, and the findings obtained as a result of the analysis are mentioned. In the conclusions and inferences part of the study, suggestions were developed in a way to shed light on future practitioners and future studies.

\section{Literature Review and Hypotheses}

The concept of perceived organizational support (POS) was first mentioned in the literature in an article published by Eisenberger et al. (1986). This concept is expressed as the perception of employees about valuing and caring for themselves due to their contribution to the organization or institution they are affiliated with. The appreciation of the work or duties performed by the employees by the organization and the fact that this appreciation is seen by someone increases the performance of the employee and is also important for the organization (Sökmen et al., 2015: 127). Employees' feeling that they are valued by the organizations they are members of and knowing that this is done voluntarily by the organization creates a positive perception of faith and loyalty towards the organization. At this point, employees exhibit a higher performance by making the work or tasks of the organization they are a member of more meaningful (Rhoades \& Eisenberger, 2002: 698). Perceived organizational support is an important motivation factor affecting employee performance by showing a more effective performance at work (from Armeli et al. as cited in Kurt, 2013). 
Kara, E. \& G. Kırpık \& A. Kaya (2021), "The Mediating Role of Organizational Identification in the Effect of Perceived Organizational Support on Employee Performance", Sosyoekonomi, 29(49), 47-64

Perceived organizational support (POS) is a concept related to the extent to which an organization or institution is concerned with the well-being of individuals working under its roof and to what extent it cares about the employee's contribution (Sökmen et al., 2015: 127). POS can be defined as "the general belief that organizations attach to their employees' contribution and welfare" (Liu \& Ding, 2012). POS guides the effective work behaviour on the staff. Individuals who gain the support of the organization of which they are a member show commitment to the jobs they are responsible for, and the thought of leaving the organization decreases due to the establishment of high trust (Eisenberger, 1990; Eisenberger et al., 1997). According to the theory of social change, which is one of the basic theories on which perceived organizational support is based, as Shore \& Tetrick (1991) stated, better perception and meaning of organizational support by the employee (Cropanzano \& Mitchell, 2005) They stated that their behaviours and attitudes towards them will be explained more clearly with this theory (Doğru, 2016: 18). Employees with a high POS level tend to exhibit attitudes in line with the interests of the organization they are a member of, and this situation highlights the social change theory developed by Blau (1964). Within the framework of this theory, team members within the same organization can contribute to the development of business relations with each other and social change (Cropanzano \& Mitchell, 2005; Hekman et al., 2009).

In studies on perceived organizational support and employee performance; Shore and Wayne (1993), Searle et al. (2001) stated that perceived organizational support had a positive significant effect on employee performance, and Rhoades \& Eisenberger (2002), who carried out a similar study, stated that perceived organizational support increased satisfaction in employees and therefore had a significant effect on job performance. Akkoç et al. (2012) emphasized that organizational support is important for the development of employees and therefore has a positive effect on their performance. In addition, in the study conducted by Yilmaz (2016) on 5-star hotel cooks, it was stated that perceived organizational support positively affected employee performance, and in the study conducted by Bacaksiz (2016) on nurses working in the public sector, it was stated that organizational support positively affected employee performance. In line with the literature research, the first hypothesis of the research was determined as follows.

\section{H1: Perceived organizational support positively affects employee performance.}

Organizational identification (OI) is the ability of an employee to express himself/herself with the institution he/she is a member of and feel that he/she belongs to that institution (Kerse \& Karabey, 2017: 380). Over time, the concept of organizational identification took place in the literature after the 1970s. Since 1970, different definitions have been made on this concept, and more emphasis has started on it. According to the literature, the concept of organizational identification is defined in different ways. For example, organizational identification is the combination and harmonization of personal goals and corporate goals (Hall et al., 1970: 176-177), and it is the employee's role in achieving corporate goals and implementing corporate principles (Buchanan, 1974: 533), and it is the ability of individuals to use the sentences they use to express their institutions 
while expressing themselves (Dutton et al., 1994). For this concept, many definitions have been made in the literature, but one of the most striking expressions is the definition made by Ashforth \& Mael (1989). The definition is as follows; organizational identification is the employee's belonging to his/her institution, or the ability to feel unity with the institution, and the ability to individually accept all positive and negative situations of the institution (Ashforth \& Mael, 1989: 34). In addition, according to another definition, organizational identification is expressed as the employee's self-evaluation process (Riketta, 2005: 360), as well as the sensory process that the employee experiences about the organization or the institution. In general, this evaluation process is an evaluation by considering all aspects of the institution or organization the employee is a member of (Çakınberk et al., 2011: 93). Finally, according to Van Dick (2004: 175), organizational identification is the fact that the employee includes this process of behavioural evaluation as well as the sensory and cognitive process that the employee feels towards the organization, he or she is a member of.

In studies on POS and organizational identification, findings supporting the purpose of this study have been reached. For example, as a result of the research conducted by Cho and Treadway (2016) on bank employees and graduate students, it was found that there is a positive and correct relationship between POS and OI, and it was stated that employees with a high perception of organizational support will have a high level of organizational identification. By Sluss et al. (2008) on multinational company employees in the USA; on service organizations by Cheung \& Law (2008); on workers in the defence industry by Turunç and Çelik (2010); by Özdemir (2010) on primary school teachers working in 8 state schools in Ankara; by Zagenczyk et al. (2011) on university employees and some business lines; and by Ertürk (2010) in the studies conducted on blue-collar shipyard employees, it was determined that POS had a positive effect on organizational identification. In this direction, based on the literature and study findings mentioned above, the following hypothesis has been created to determine the relationship between perceived organizational support (POS) and organizational identification (OI).

\section{H2: Perceived organizational support positively affects organizational identification.}

Employee performance (EP) concept is one of the important concepts that all businesses operating in the service sector should focus on today. Regarding the concept of employee performance, in the literature, it is seen that researchers have different meanings by making different definitions. The concept of performance is defined as the degree of achievement of the objectives of the work carried out in a certain time period (Tutar \& Altınöz, 2010: 201). The concept of employee performance is the comparison with the organizational success criteria determined according to the individual abilities of the employees (Gümüştekin \& Öztemiz, 2005: 280). At this point, it is the performance of the employee individually, within the limits he can do in accordance with the job defined. If an organization is to choose a method to reward its employee, this method must necessarily be related to the employee's performance rating. In terms of businesses, if it is necessary to define the concept of performance, it is expressed as a service or an idea in order to perform 
Kara, E. \& G. Kırpık \& A. Kaya (2021), "The Mediating Role of Organizational Identification in the Effect of Perceived Organizational Support on Employee Performance", Sosyoekonomi, 29(49), 47-64

the task to be carried out in the best way and to reach the goals set by the business within the framework of the criteria determined by the enterprises (Pugh, 1991: 7-8). When the literature was examined, it was concluded that, as a result of the study conducted by Akkoç et al. (2012) on whether POS had an effect on performance, the results obtained were positive, and POS had a partial mediating role on performance.

On organizational identity and employee performance, McGregor (1967), Riketta (2005), Carmeli et al. (2007) and Liu et al. (2011), it has been revealed that identification with the organization has a significant effect on performance. In the study by Yaman (2011), it was stated that organizational identification increases employee motivation, job satisfaction and commitment, and thus has a positive effect on performance. In addition, in the study conducted by Newman et al. (2014), it was reported that organizational identity helps high performance due to its positive psychological effect on employees. Therefore, according to the mentioned literature, the third hypothesis of the research was formed as follows.

\section{H3: Organizational identification positively affects employee performance.}

Considering the studies on the mediating role of organizational identification in the relationship between POS and employee performance, it is seen that these studies are limited. In the studies; on the nurses working in public hospitals in the European side of Istanbul, by Bacaksız (2016); over 300 research assistants by Sökmen et al. (2015); on the employees of 13 enterprises operating in different sectors in China by Shen et al. (2014); by Gillet et al. (2013) on 323 nurses working in France; conducted by Hekman et al. (2009) on physicians, it is seen that organizational identification has a mediating role in the relationship between POS and employee performance. In the light of the above theory and study findings, it is thought that job satisfaction has an increasing effect on the effect of transformational leadership on employee performance. In this direction, the following hypothesis has been created.

\section{H4: Organizational identification has a mediating role in the effect of perceived organizational support on employee performance.}

\section{Research Method}

In this study, which aims to determine the mediating role of organizational identification in the effect of perceived organizational support on employee performance, first of all, information about the population and sample of the research and the scales used in the research are given. Then, analysis was made for the research model, which was created in the light of the data obtained from the research sample. In this direction, confirmatory factor analysis (CFA) were conducted for the scales of the study, and the correlations between research variables were determined. Afterwards, the goodness of fit tests of the research model were conducted with the structural equation model established within the framework of the research model, and the results of the regression analysis and mediation test between variables were presented. 


\subsection{Research Model}

In accordance with the literature and hypotheses, the following research model has been created in order to reveal the relationships between variables. In this study, as Karasar (1995) stated, the relational screening model, which is a research model, which tries to determine whether two or more variables are in relation and whether there is a change together, was preferred. In Figure 1, the conceptual model of the research that covers three different variables is shown.

Figure: 1

\section{Relationships Among the Research Variables}

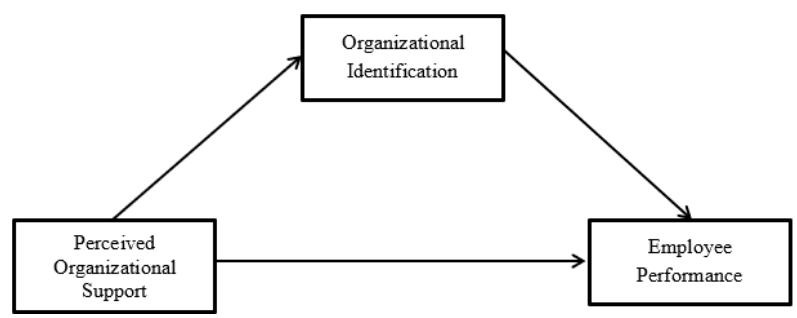

\subsection{Research Population and Sample}

The population of the research consists of public and private banks employee operating in Adana and Osmaniye. The sample of the research is bank employees in Adana and Osmaniye. The necessary data set used in the research was obtained by applying a questionnaire to 414 people with convenience sampling method. However, the minimum number of questionnaires required for this study was calculated by using the formula below in this formulation, $\mathrm{n}$ : sample size, $\mathrm{N}$ : population volume, $\mathrm{P}$ : probability of occurrence of a given event, $\mathrm{Q}=1-\mathrm{P}, \mathrm{Z}$ value $(1-\alpha)$ test statistic at confidence level and $\mathrm{d}$ : amount of tolerance. In addition, the required minimum sample size was determined as $95 \%$ confidence interval and 5\% tolerance. According to this formula, the number of questionnaires to be applied was calculated as 384 (Özer, 2004; Yakut, 2020: 3286):

$$
\begin{aligned}
& n=\frac{N P Q Z^{2}}{(N-1) d^{2}+P Q Z^{2}} \\
& n=\frac{264373(0.5)(0.5)(1.96)^{2}}{(264373-1) 0.05^{2}+(0.5)(0.5)(1.96)^{2}} \cong 384
\end{aligned}
$$

168 of the employees are women and 246 of them are men. 126 of the employees are in the age range of 18-31, 138 of them are in the age range of 32-38, 109 of them are in the age range of 39-51 and 21 of them are in the age range of 52 and over. In terms of work experience, 51 of the employees are less than 1 year, 148 employees 1-3 years, 109 employees 4-7 years, 69 employees 8-11 years, 29 employees 12-20 years, and 8 employees 21 years or more, has experience. 
Kara, E. \& G. Kırpık \& A. Kaya (2021), "The Mediating Role of Organizational Identification in the Effect of Perceived Organizational Support on Employee Performance", Sosyoekonomi, 29(49), 47-64.

\subsection{Scales of the Study}

Expressions in all scales in the questionnaire forms were measured with a 5-point Likert type scale. For the reliability of the scales, the Cronbach Alpha value was used, and the mean and standard deviation values were calculated for all the expressions in the scales. It was found that the reliability values of the factors in all of the statements in the questionnaire form were 0.70 and above (Nunnally, 1978).

- Organizational Support Scale: The short version of the five-item scale, developed by Rhoades et al. (2001) and validated in Turkish by Çınar (2013), was used. The reliability coefficient of this scale was determined as 0,88 .

- Employee Performance Scale: The scale consisting of one dimension and four expressions, adapted from the study of Kirkman and Rosen (1999) by Sigler \&Pearson (2000), was used in this study. Turkish adaptation of the scale was made by Çöl (2008). The reliability coefficient of this scale was found to be 0,91 .

- Organizational Identification Scale: It is a one-dimensional scale consisting of six expressions, developed by Mael \& Ashforth (1992), then adapted into Turkish by Tak \& Aydemir (2004). The reliability coefficient of this scale was found to be 0,83 .

\section{Findings}

SPSS and AMOS statistical package programs were used for the analysis of the data collected within the scope of the research. In order to reveal the reliability levels of the scales used in the study, the Cronbach's Alpha coefficient was taken into account, and descriptive statistics for the variables were determined. Confirmatory factor analysis (CFA) was performed to determine the structural validity of the measurement model presented in the study, and the convergence and convergence validities were revealed. In addition to these, the relationships between the variables discussed in the study were determined by performing Pearson correlation analysis. In testing the hypotheses put forward in the study, structural equation model (SEM) analysis was handled, and thus, direct effects, indirect effects and total effects, which were aimed to be revealed among variables, were determined. The correlation values between the variables and the reliability and descriptive statistics of the variables are included in Table 1 . The fact that the skewness and kurtosis values of the mean of the variables are between +2 and -2 shows that the data is normal distributed. When Table 1 below is examined, it has been found that there are positive and significant relationships between "Perceived Organizational Support (POS)", "Employee Performance (EP)" and "Organizational Identification (OI)".

In the study, first-order multifactorial structure was tested with confirmatory factor analysis (CFA), preferring the AMOS program, in order to determine the validity of the scales. Due to the normal distribution of the data, the maximum likelihood estimation method was used for this (Gürbüz \& Şahin, 2016). The coefficients obtained as a result of the analysis are shown in Figure 2. According to the aforementioned findings, factor loads 
took high values ranging from 0,579 to 0,887 , and all of these factor loads were found to be statistically significant.

Table: 1

\section{Descriptive Statistics and Correlation Coefficients}

\begin{tabular}{|l|c|c|c|c|c|c|c|}
\hline & Mean & Sd. & Skewness & Kurtosis & 1 & 2 & 3 \\
\hline 1. Perceived Organizational Support (POS) & 4.20 & .72 & -1.86 & 1.28 & $(.88)$ & & \\
\hline 2. Employee Performance (EP) & 4.40 & .60 & -1.21 & 1.30 & $.572^{* *}$ & $(.91)$ & \\
\hline 3. Organizational Identification (OI) & 4.10 & .71 & -1.71 & 1.55 & $.423^{* *}$ & $.558^{* *}$ & $(.83)$ \\
\hline
\end{tabular}

** $p<.001, n=414$, values given in parentheses are Cronbach's Alpha $(\alpha)$ values.

Figure: 2

\section{Confirmatory Factor Analysis (CFA)}

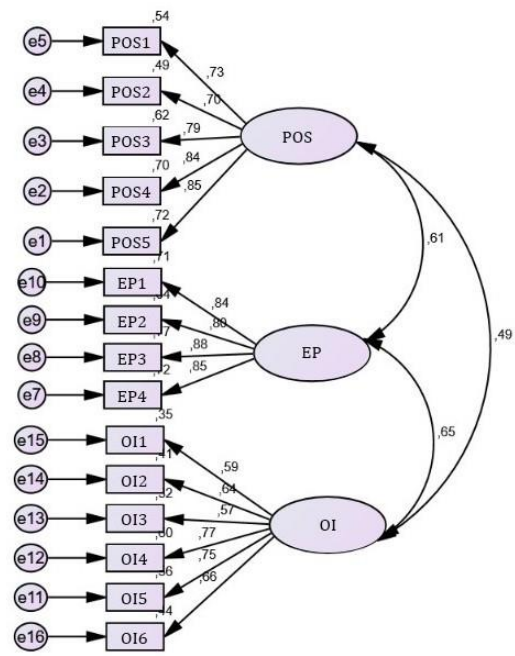

As a result of the first level confirmatory factor analysis (CFA) of the scale, acceptable good fit values were reached in the values of fit indices. The confirmatory factor analysis (CFA) results are presented in Table 2 below. The goodness of fit values obtained as a result of CFA were determined as " $\chi 2$ / $\mathrm{df}=2,48$; $\mathrm{SRMR}=0,34$; IFI $=0,96$; TLI $=0,95$; $\mathrm{CFI}=0,96$; RMSEA $=0,60$ ", and these values show that the model is in very good fit. In addition, these results indicate that the predicted theoretical structure of the three factors is confirmed.

Table: 2

Goodness of Fit Statistics for the Scales and Research Model

\begin{tabular}{|c|c|c|c|c|c|c|c|c|}
\hline Godness of Fit Values & $\chi^{2}$ & df & CMIN/DF & SRMR & IFI & CFI & TLI & RMSEA \\
\hline Perceived Organizational Support & 13.987 & 3 & 4.662 & .012 & .990 & .990 & .998 & .073 \\
\hline Employee Performance & 4.282 & 3 & .199 & .004 & .999 & .999 & .997 & .032 \\
\hline Organizational Identification & 18.654 & 8 & 2.332 & .028 & .986 & .986 & .974 & .057 \\
\hline Measurement Model & 216.304 & 87 & 2.486 & .034 & .963 & .963 & .955 & .060 \\
\hline
\end{tabular}


In the next part of the study, in order to test the research hypotheses and the mediating effect, a path analysis model was established for the mediating role of organizational identification in the effect of perceived organizational support on employee performance. The result regarding the established structural model is shown in Figure 3.

Figure: 3

\section{Structural Equation Model (SEM) and Standardized Path Coefficients}

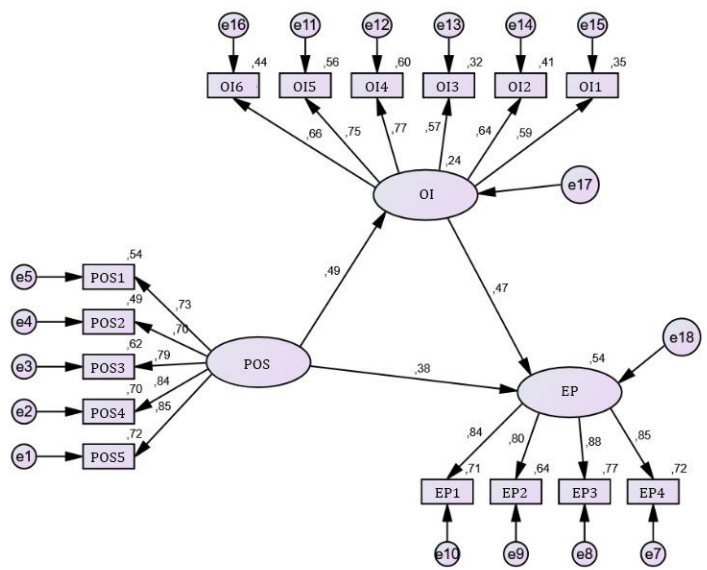

Regarding the model given in Figure 3, H1: "Perceived organizational support positively affects employee performance.", H2: "Perceived organizational support positively affects organizational identification.", H3: "Organizational identification positively affects employee performance" and H4: "Organizational identification has a mediating role in the effect of perceived organizational support on employee performance." The research hypotheses were tested on the structural model in order to evaluate the hypotheses and the effect of the intermediary model, and the results are shown in Table 3. In terms of testing the mediation role, the highest likelihood method was used with the Monte Carlo Parametric Boostrap option with a 95\% confidence interval consisting of 5000 samples to look at the significance of indirect effects. The upper and lower values for the confidence intervals are presented in Table 3.

Table: 3

\section{Mediation Analysis}

\begin{tabular}{|c|c|c|c|c|c|c|}
\hline \multirow{2}{*}{\multicolumn{3}{|c|}{ Tested Path }} & \multirow{3}{*}{$\begin{array}{c}\beta \\
0,488^{*+* *}\end{array}$} & \multirow{3}{*}{$\begin{array}{c}\text { SE } \\
0,47\end{array}$} & \multicolumn{2}{|c|}{$\mathrm{BC} \% 95 \mathrm{CI}$} \\
\hline & & & & & LB & UB \\
\hline Perceived Organizational Support & -.-> & Organizational Identification & & &, 37 & .59 \\
\hline Organizational Identification & $--->$ & Employee Performance & $0,473^{* \ldots+1}$ & 0,49 &, 35 & .57 \\
\hline Perceived Organizational Support & $-->$ & Employee Performance & & & & \\
\hline Total Effect (c) & & & 0,607 & 0,37 & .51 & .68 \\
\hline Direct Effect (c') & & & $0,377^{*+*+}$ & - &, 25 & 48 \\
\hline Indirect Effect (axb) & 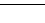 & - & $0,230^{*+*}$ & - & 16 & 31 \\
\hline
\end{tabular}


Kara, E. \& G. Kırpık \& A. Kaya (2021), "The Mediating Role of Organizational Identification in the Effect of Perceived Organizational Support on Employee Performance", Sosyoekonomi, 29(49), 47-64.

As a result of the analysis, it was revealed that perceived organizational support has a significant positive effect on organizational identification $(\beta=, 488, p<.001,95 \%$ CI [,37, .59]). In this case, the $\mathbf{H 2}$ hypothesis was supported. This result shows that perceived organizational support has an increasing effect on the organizational identification of the employees due to the work done. Organizational identification has a significant positive effect on employee performance $(\beta=, 473, \mathrm{p}<.001,95 \%$ CI $[, 35, .57])$. In this case, the $\mathbf{H 3}$ hypothesis was supported. However, the total $(\beta=.607, \mathrm{p}<.001,95 \%$ CI $[.51, .68])$ and direct $(\beta=, 377, \mathrm{p}<.001,95 \%$ CI $[, 25, .48])$ has been observed to have a significant positive effect. In addition, it was revealed that perceived organizational support has an indirect (= $.230, \mathrm{p}<.001,95 \%$ CI $[.16, .31])$ significant effect on employee performance. Hence, the $\mathrm{H1}$ and $\mathbf{H 4}$ hypothesis was supported. In the light of these results, four hypotheses of the study were accepted. It was stated by Zhao et al. (2010) and Baron and Kenny (1986) that in order to talk about a mediating effect, VAF (Variance Accounted For) value should be calculated, and if VAF $<0.20$, there is no mediating effect; If $0.20 \leq \mathrm{VAF} \leq 0.80$, there is a partial intermediation effect; and if the $\mathrm{VAF} \geq 0,80$, it has a full intermediary effect. Since $\mathrm{VAF}=($ Indirect Effect $) /($ Indirect Effect + Direct Effect $)=0,23 /(0,23+0,37)=0,38<0,80$, it can be said that organizational identification in the model has a partial mediating effect.

Therefore, it can be said that organizational identification has a partial mediating effect according to the research model. According to these findings. Organizational identification has a "partial mediating role" in the effect of perceived organizational support on employee performance. Because, Boostrap lower and upper confidence interval values obtained by percentage method do not include 0 (zero) value. This finding shows that organizational identification has an enhancing effect on the effect of perceived organizational support on employee performance, the main purpose of which is to give employees confidence and increase their work efforts.

\section{Conclusion, Discussion and Suggestions}

Developments in the service sector in recent years have started a fierce race between organizations, and accordingly, organizations have resorted to different ways to increase employee performance. Improving the work environment and economic status of the employees causes significant increases in employee performance. In this context, perceived organizational support is thought to have a regulatory and developmental effect between the organization and the employee. On the other hand, employees can identify themselves with the organization they are affiliated with only through organizational support. Perceived organizational support and identification has become an increasingly important issue for organizations in increasing employee performance in recent years. Based on this importance, in this study conducted on public and private banks in Adana and Osmaniye provinces in order to determine the mediating role of organizational identification in the effect of POS on employee performance, the data collected through the survey were statistically evaluated.

As a result of the statistical analysis, it was concluded that POS had a significant positive effect on organizational identification. This result is based on studies conducted to 
Kara, E. \& G. Kırpık \& A. Kaya (2021), "The Mediating Role of Organizational Identification in the Effect of Perceived Organizational Support on Employee Performance", Sosyoekonomi, 29(49), 47-64

determine the effect of perceived organizational support on organizational identification (Knippenberg \& Sleebos, 2006; Edwards \& Peccei, 2010; Sluss et al., 2008; Cheung \& Law, 2008; Eisenberger et al., 2001) consistent with the results. This finding indicates that perceived organizational support increases organizational identification on the employee. Accordingly, as stated by Cheney (1983), it can be said that the level of organizational identification is higher in organizations and institutions where value-oriented incentives are offered. However, this finding is confirmed by the statement stated by Ashforth et al. (2008) that "organizational identification is the process of establishing a bond between the employee and the organization and understanding each other by feeling that the employee belongs to the organization". In parallel with this situation, with the statement stated by Rhoades and Eisenberger (2002) that "employees can meet their needs by receiving mutual support with respect, love and trust with the organization they work for, and accordingly, employees add their membership to their social identity" findings were supported (Zagenczyk et al., 2011: 260). In addition, this finding supports the situation stated by Tyler and Blader (2003) that "employees who are loved and counted by their organizations and who are evaluated in higher positions will increase the degree of organizational identification and exhibit some supportive behaviours". As a matter of fact, these different approaches have a positive impact on employees, and allow for an increase in employee performance. According to all this information, it is possible to evaluate that the socioeconomic needs of the employees can be met with perceived organizational support.

As a result of the analysis conducted to determine the mediating role of organizational identification in the effect of POS on employee performance for the main purpose of the study, it was determined that organizational identification has a partial mediating role in the effect of POS on employee performance. This result shows that POS has an indirect effect on employee performance both directly and through organizational identification. In this respect, it is possible to evaluate that the performance may increase as a result of the employees seeing themselves as a part of the organization benefiting both the institution and the work done. These findings are consistent with the results of the study examining the relationship between POS and employee performance (Hekman et al., 2009; Sluss et al., 2008; Gillet et al., 2013). In addition, other studies examining the relationship between POS, employee performance and organizational identification (Shen et al., 2014; Gillet et al., 2013; Hekman et al., 2009; Sökmen et al., 2015; Bacaksız, 2016; Eisenberger et al., 1986) is also compatible with the results. In addition, as stated by Turunç \& Çelik (2010), it has been concluded that if employees' expectations about the organization they work for are met, and they identify with the organization, there is an increase in the performance levels of employees, and this finding strengthens the effect of perceived organizational support on employee performance. On the other hand, another finding is that "an employee who thinks that his/her organization will stand by him and his/her organization will support him/her even if they encounter negative events during the process of their life, increase the positive relationship between them and their current organization, and thus increase their direct performance. It can be expressed as". 
The scales used in the research are on a 5-point Likert scale and were created to determine whether to agree with certain expressions. However, common method deviation may occur as a result of using the same scale type (Likert, semantic differences, etc.) for variables. This means that all three variables are determined by Likert method, and there is the possibility that there may be an effect on the opinions of the people who filled out the questionnaire (Güğerçin \& Ay, 2016). Therefore, the fact that the scales used in the study are on a 5-point Likert scale is one of the limitations of the study. Another limitation of the research is that the research was conducted with employees operating in the service sector in only one region. However, all the results obtained as a result of this study should be evaluated within the scope of the sample that was researched, the survey method determined and the research limitations. In addition, since the research is conducted in a certain period of time, attitudes and perceptions may change over time, this study is limited to the process in which it was carried out (Aslan, 2020: 209). Therefore, the application of a similar research to different sectors and employees can be recommended for researchers.

The most important contribution of this study to the literature is that it has been proven that organizational identification has an increasing effect on the effect of perceived organizational support on employee performance. In this respect, it is thought that the research will contribute to the literature. For future studies, it is recommended to carry out studies that consider factors such as organizational justice, organizational cynicism, organizational culture and organizational commitment as mediator variables in the effect of factors such as job satisfaction, self-efficacy, and job stress on employee performance. For practitioners, it is suggested that the positive perception of organizational support towards motivation and wages in the organization is an important issue in organization-employee interaction, should not be ignored. In addition, in order to increase the performance of the employees and to identify with the organization, it is recommended to support the employees in an organizational way, and to carry out activities that will motivate them to work and increase their level of satisfaction with wages.

\section{References}

Akkoç, İ. \& A. Çalışkan \& Ö. Turunç (2012), “The Effect of Development Culture and Perceived Organizational Support to The Job Satisfaction and Job Performance: The Mediating Role of Trust”, Journal of management and Economics, 19(1), 105-135.

Ashforth, B.E. \& F. Mael (1989), "Social Identity Theory and the Organization”, Academy of Management Journal, 14(1), 20-39.

Aslan, H. (2020), "Mediating Role of Psychological Ownership in Servant Leadership's Effect on Job Satisfaction”, Business and Management Studies: An International Journal, 8(1), 196-212.

Bacaksız, F.E. (2016), “Örgütsel Erdemliliğin Hemşirelerin Örgütle Özdeşleşme Düzeylerine ve Performanslarına Etkisi: Algılanan Örgütsel Desteğin Aracı Rolü’, Unpublished Dissertation, Istanbul University, Institute of Health Sciences, Department of Management in Nursing, Nursing Management Program. 
Kara, E. \& G. Kırpık \& A. Kaya (2021), "The Mediating Role of Organizational Identification in the Effect of Perceived Organizational Support on Employee Performance”, Sosyoekonomi, 29(49), 47-64.

Baron, R.M. \& D.A. Kenny (1986), “The Moderator-Mediator Variable Distinction in Social Psychology Research: Conceptual, Strategic and Statistical Considerations”, Journal of Personality and Social Psychology, 51(6), 1173-1182.

Blau, P.M. (1964), Exchange and power in social life, New York: Wiley.

Buchanan, B. (1974), "Building Organizational Commitment: The Socialization of Managers in Work Organizations", Administrative Science Quarterly, 19(4), 533-546.

Çakınberk, A. \& N. Derin \& E.T. Demirel (2011), "Shaping of Organizational Identification by Organizational Commitment: Example of Private Education Institutions in Malatya and Tunceli”, Journal of Business Research-Turk, 3(1), 89-121.

Carmeli, A. \& G. Gilat \& D.A. Waldman (2007), "The Role of Perceived Organizational Performance in Organizational Identification, Adjustment and Job Performance”, Journal of Management Studies, 44(6), 972-992.

Cheung, M.F. \& M.C. Law (2008), "Relationships of Organizational Justice and Organizational Identification: The Mediating Effects of Perceived Organizational Support in HongKong”, Asia Pacific Business Review, 14(2), 213-231.

Cho, J. \& D.C. Treadway (2016), “Organizational Identification and Perceived Organizational Support as Mediators of the Procedural Justice-Citizenship Behaviour Relationship: A Cross-Cultural Constructive Replication", European Journal of Work and Organizational Psychology, 20(5), 631-653.

Çınar, Ö. (2013), “The Mediating Role of Organizational Citizenship Behaviour by Structural Equation Modelling on Job Satisfaction, Organizational Commitment, Organizational Support and Organizational Justice Influence on Organizational Outcomes: A Field Study in the Banking of Kahramanmaraş", Unpublished Dissertation, Kahramanmaraş Sütçü İmam University, Institute of Social Sciences, Türkiye.

Çöl, G. (2008), “The Effects of Perceived Empowerment on Employee Performance”, Doğus University Journal, 9(1), 35-46.

Cropanzano, R. \& M.S. Mitchell (2005), "Social Exchange Theory: An Interdisciplinary Review", Journal of Management, 31(6), 874-900.

Cullen-Lester, K. \& B.D. Edwards \& W.C. Casper \& K.R. Gue (2014), “Employees’ Adaptability and Perceptions of Change-Related Uncertainty: Implications for Perceived Organizational Support, Job Satisfaction, and Performance", Journal of Business and Psychology, 29(2), 269-280.

Doğru, Ç. (2016), "The Effects of Perceived Organizational Support and Leader-member Exchange on Contextual Performance: A Research in the Banking Sector in Ankara", Unpublished Dissertation, Gazi University Institute of Social Sciences Department of Business Administration, Ankara/Türkiye.

Dutton, J.E. \& J.M. Dukerich \& C.V. Harquail (1994), "Organizational Images and Member Identification”, Administrative Science Quarterly, 39, 239-263.

Edwards, M.R. \& R. Peccei (2010), "Perceived Organizational Support, Organizational Identification and Employee Outcomes: Testing A Simultaneous Multifoci Model”, Journal of Personnel Psychology, 9(1), 17-26.

Eisenberger, R. \& J. Cummings \& S. Armeli \& P. Lynch (1997), "Perceived organizational support, discretionary treatment, and job satisfaction", Journal of Applied Psychology, 82(5), 812820 . 
Kara, E. \& G. Kırpık \& A. Kaya (2021), "The Mediating Role of Organizational Identification in the Effect of Perceived Organizational Support on Employee Performance", Sosyoekonomi, 29(49), 47-64.

Eisenberger, R. \& P. Fasolo \& V. Davis-LaMastro (1990), "Perceived organizational support and employee diligence, commitment, and innovation", Journal of Applied Psychology, 75(1), 51-59.

Eisenberger, R. \& R. Huntington \& S. Hutchison \& D. Sowa (1986), "Perceived Organizational Support", Journal of Applied Psychology, 71(3), 500-507.

Eisenberger, R. \& S. Armeli \& B. Rexwinkel \& P.D. Lynch \& L. Rhoades (2001), "Reciprocation of Perceived Organizational Support”, Journal of Applied Psychology, 86(1), 42-51.

Erkoç, Ç.İ. (2015), Regulating role of self- sufficiency factor with regard to the relationship between perceived organizational support and work performance: a research in banking business, İstanbul Kültür University, İstanbul.

Ertürk, A. (2010), "Exploring Predictors of Organizational Identification: Moderating Role of Trust on The Associations Between Empowerment, Organizational Support and Identification", European Journal of Work and Organizational Psychology, 19(4), 409441.

Gillet, N. \& P. Colombat \& E. Michinov \& A.M. Pronost \& E. Fouquereau (2013), "Procedural Justice, Supervisor Autonomy Support, Work Satisfaction, Organizational Identification and Job Performance: The Mediating Role of Need Satisfaction and Perceived Organizational Support", Journal of Advanced Nursing, 69(11), 2560-2571.

Güğerçin, U. \& Ü. Ay (2016), "The Impact of Ethics Position on Organizational Citizenship Behavior: An Empirical Study in the Context of Ethics Position Theory", Journal of Social and Economic Research, 19(32), 34-46.

Gümüştekin, G. \& A. Eren \& B. Öztemiz (2005), "Interaction of Stress with Productivity and Performance in Organizations", Çukurova University, Journal of Social Sciences Institute, 14(1), 271-288.

Gürbüz, S. \& F. Şahin (2016), Sosyal Bilimlerde Araştırma Yöntemleri Felsefe, Yöntem, Analiz, $3^{\text {rd }}$ Edition, Seçkin Yayıncılık: Ankara.

Hair, J.F. \& W.C. Black \& B.J. Babin (2010), Multivariate Data Analysis: A Global Perspective, $7^{\text {th }}$ Edition, Prentice Hall: New Jersey.

Hall, D.T. \& B. Schnider \& T.N. Harold (1970), "Personal Factors in Organizational Identification", Administrative Science Quarterly, 15(2), 176-190.

Hekman, D.R. \& G.A. Bigley \& J.F. Hereford (2009), "Combined Effects of Organizational and Professional Identification on the Reciprocity Dynamic for Professional Employee", Academy of Management Journal, 52(3), 506-526.

Karaalioğlu, F.Z. (2019), “Algılanan Örgütsel Destek ile İş Performansı İlişkisinde Örgütsel Özdeşleşme, İş Tatmini ve Örgütsel Vatandaşlık Davranışının Aracı Rolü”, Unpublished Dissertation, Istanbul Commerce University, Institute of Social Sciences, Department of Business Administration, Istanbul.

Karasar, N. (1995), Bilimsel Araştırma Yöntemi: Kavramlar, İlkeler ve Teknikler, Sim Matbaası: Ankara.

Kerse, G. \& C. Karabey (2017), "The Effects of Perceived Organizational Support on Organizational Identification: The Mediating Role of Organizational Cynicism", MANAS Journal of Social Studies, 6(4), 375-398.

Kirkman, B.L. \& B. Rosen (1999), "Beyond Self-Management: Antecedents and Consequences of Team Empowerment", Academy of Management Journal, 42(1), 58-74. 
Kara, E. \& G. Kırpık \& A. Kaya (2021), "The Mediating Role of Organizational Identification in the Effect of Perceived Organizational Support on Employee Performance”, Sosyoekonomi, 29(49), 47-64.

Knippenberg, D.V. \& E. Sleebos (2006), “Organizational Identification Versus Organizational Commitment: Self-Definition, Social Exchange and Job Attitudes", Journal of Organizational Behavior, 27(5), 571-584.

Kurt, E. (2013), "The Mediating Effect of Occupational Commitment on the Relationship Between Perceived Social Support and Job Performance: A Research in Tourism Organizations", Master's Thesis, Ankara.

Lee, S.M. (1971), “An Empirical Analysis of Organizational Identification”, Academy of Management Journal, 14(2), 213-226.

Liu, N.T. \& C.G. Ding (2012), "General Ethical Judgments, Perceived Organizational Support, Interactional Justice, and Workplace Deviance", The International Journal of Human Resource Management, 23(13), 2712-2735.

Liu, Y. \& R. Loi \& L.W. Lam (2011), "Linking Organization Al Identification and Employee Performance in Teams: the moderating role of team-member exchange", The International Journal of Human Resource Management, 22(15), 3187-3201.

Mael, F.A. \& B.E. Ashforth (1992), "Alumni and Their Alma Mater: A Partial Test of the Reformulated Model of Organizational Identification", Journal of Organizational Behaviour, 13(2), 103-123.

McGregor, D. (1967), The Professional Manager, New York: McGraw-Hill.

Meydan, C.H. \& H. Şeşen (2015), Yapısal Eşitlik Modellemesi: AMOS Uygulamaları, $2^{\text {nd }}$ Edition. Detay Publishing: Ankara.

Newman, A. \& D. Ucbaşaran \& F. Zhu \& G. Hirst (2014), "Psychological Capital: A Review and Synthesis", Journal of Organizational Behavior, 35(1), 120-138.

Nunnally, J. (1978), Psychometric Methods, $2^{\text {nd }}$ Edition, McGraw-Hill: New York.

Özdemir, A. (2010), “Örgütsel Özdeşleşmenin Algılanan Örgütsel Destek, Cinsiyet ve Kıdem Değişkenlerine Göre İncelenmesi”, TSA, 14(1), 237-250.

Özer, H. (2004), Nitel değişkenli ekonometrik modeller: Teori ve bir uygulama, Ankara: Nobel Yayınevi

Pugh, S.D. (1991), Organizational Behaviour, Prentice Hall: UK.

Rhoades, L. \& R. Eisenberger \& S. Armeli (2001), "Affective Commitment to the Organization: The Contribution of Perceived Organizational Support", Journal of Applied Psychology, 86(5), 825-836.

Rhoades, L. \& R. Eisenberger (2002), "Perceived Organizational Support: A Review of the Literature", Journal of Applied Psychology, 87(4), 698-714.

Riketta, M. (2005), “Organizational Identification: A Meta-Analysis”, Journal of Vocational Behavior, 66, 358-384.

Searle, B. \& J.E.H. Bright \& S. Bochner (2001), "Helping People to Sort It Out: The role of Social Support in the Job Strain Model", Work \& Stress, 15(4), 328-346.

Shen, Y. et al. (2014), "Linking Perceived Organizational Support with Employee Work Outcomes in a Chinese Context: Organizational Identification as a Mediator", European Management Journal, 32, 406-412.

Shore, L.M. \& L.E. Tetrick (1991), “A Construct Validity Study of the Survey of Perceived Organizational Support”, Journal of Applied Psychology, 76(5), 637-643. 
Kara, E. \& G. Kırpık \& A. Kaya (2021), "The Mediating Role of Organizational Identification in the Effect of Perceived Organizational Support on Employee Performance", Sosyoekonomi, 29(49), 47-64.

Shore, L.M. \& S.J. Wayne (1993), “Commitment and Employee Behavior: Comparison of Affective Commitment and Continuance Commitment with Perceived Organizational Support", Journal of Applied Psychology, 78(5), 774-780.

Sigler, T.H. \& C.M. Pearson (2000), "Creating an Empowering Culture: Examining the Relationship Between Organizational Culture and Perceptions of Empowerment", Journal of Quality Management, 5(1), 27-52.

Sluss, D.M. \& M. Klimchak \& J.J. Holmes (2008), "Perceived Organizational Support as a Mediator Between Relational Exchange and Organizational Identification", Journal of Vocational Behavior, 73(3), 457-464.

Sökmen, A. \& E.B. Ekmekçioğlu \& K. Çelik (2015), "The Relationship between Perceived Organizational Support, Organizational Identification, and Manager's Ethical Behaviors: Perception of Research Assistants in Universities", Journal of Business Research Turk, 7(1), 125-144.

Tak, B. \& B.A. Aydemir (2004), “Örgütsel Özdeşleşme Üzerine İki Görgül Çalışma”, 12. Ulusal Yönetim ve Organizasyon Kongresi, Uludağ University, Bursa.

Turunç, Ö. \& M. Çelik (2010), “Örgütsel Özdeşleşme ve Kontrol Algılamalarının, Çalışanların İşten Ayrılma Niyeti ve İş Performansına Etkileri”, Atatürk University Journal of Economics and Administrative Sciences, 24(3), 163-181.

Tutar, H. \& M. Altınöz (2010), "The Effect of Organizational Climate on Employee Performance: A Study on the Employees of Ostim Manufacturing Enterprises", Ankara University SBF Journal, 65(2), 196-218.

Tüzün, İ.K. \& F. Çetin \& H.N. Basım (2013), “Örgütsel Destek ile Normlardan Sapma Davranışları İlişkisinde Özyeterliliğin Biçimlendirici Rolü”, in: K. Demirci \& G.E. Gümüştekin \& D. Ergun-Özler \& C. Giderler-Atalay (eds.), 21. Ulusal Yönetim ve Organizasyon Kongresi Bildiriler Kitabl, Nobel Akademik Yayıncılık, 344-347.

Tüzün, İ.K. \& İ. Çağlar (2008), "The Concept of Organizational Identification and the Relationships of Organizational Communication”, Journal of Yasar University, 3(9), 1011-1027.

Tyler, T.R. \& S.L. Blader (2003), “The Group Engagement Model: Procedural Justice, Social Identity and Cooperative Behavior", Personality and Social Psychology Review, 7(4), 349-361.

Van Dick, R. (2004), "My Job is My Castle: Identification in Organizational Contexts", International Review of Industrial and Organizational Psychology, 19, 171-203.

Wang, G. \& R.G. Netemeyer (2002), “The Effects of Job Autonomy, Customer Demandingness, and Trait Competitiveness on Salesperson Learning, Self-Efficacy and Performance", Journal of the Academy of Marketing Science, 30(3), 217-228.

Yakut, E. (2020), "Multinominal Probit Model İle Konut Seçimine Etki Eden Faktörlerin Belirlenmesi: Osmaniye İli Uygulaması", Business \& Management Studies: An International Journal (BMIJ), 8(3), 3274-3301.

Yaman, T. (2011), "Yöneticilerin Paternalist (Babacan) Lider Davranışlarının Çalışanların Örgütsel Özdeşleşmelerine, İş Performanslarına ve İşten Ayrılma Niyetlerine Etkisi: Öze Sektörde Uygulama", Master's Thesis, Kara Harp Okulu, Savunma Bilimleri Enstitüsü, Ankara. 
Yılmaz, A. (2016), “Algılanan Örgütsel Destek Ortamında İş Stresi ve İş Yaşam Kalitesinin İş Performansı Üzerine Etkisinin Araştırılması: İstanbul'da Bulunan Beş Yıldızlı Otellerde Çalışan Aşçılar Üzerine Bir Araştırma", Unpublished Dissertation, İstanbul University, Institute of Social Sciences, İstanbul.

Y1lmaz, H. \& A.Ş. Görmüş (2012), "Investigation of the Effects of Strategic Entrepreneurship on Perceived Organizational Support and Organizational Learning: An Empirical Study in Textile Industry", Journal of Yasar University, 26(7), 4483-4504.

Zagenczyk, T.J. \& R. Gibney \& W.T. Few \& K.L. Scott (2011), "Psychological contracts and organizational identification: The mediating effect of perceived organizational support", $J$ Labor Res, 32(3), 254-281.

Zhao, X. \& J.G. Lync \& Q. Chen (2010), "Reconsidering Baron and Kenny: Myths and Truths about Mediation Analysis”, Journal of Consumer Research Inc., 37(2), 197-206. 